\title{
Ibn Khaldun: Scientific Instruction as Prolonging the Polity ${ }^{*}$
}

\section{İbn Haldun: Devlet'in Ömrünü Uzatmak Maksatlı IIImi Eğitim}

\author{
Umar Shareef \\ Tufts University, United States \\ umar.shareef@tufts.edu
}

\begin{abstract}
At a time when various forces threaten the continued life of democracy, Ibn Khaldun's writings on education offer renewed importance to building longer lasting political regimes. In this paper, I argue that Ibn Khaldun views education as a crucial element for prolonging the polity and postponing the inevitable fall of dynasties. In the first part of the paper, I open with a discussion that situates his views within three broad debates in the literature: the first on Ibn Khaldun's Muqaddima's normative or descriptive nature; the second on its pessimistic or optimistic vision of human history; and the third on the role of statecraft. The second part of the paper identifies education as a crucial element for realizing the state's ultimate objective: securing the context necessary for achieving human perfection. It also shows how scientific instruction strengthens the political well-being of the state by educating future leaders as well as perfecting the intellectual and moral character of the polity. I conclude with a discussion of the ideal instructor and Ibn Khaldun's proposed teaching pedagogy. My paper has the potential to bring together Islamic and Western political thought and expands the political options available to Muslims within their own intellectual tradition. Ultimately, I contribute to the deparochialization of western-dominated political theory by seriously contextualizing Ibn Khaldun within the Islamic tradition.
\end{abstract}

Keywords: Ibn Khaldun, Education, Scientific Instruction, Politics, Political Science

Öz: Demokrasilerin farklı amiller tarafından tehdit altına alınmış olduğu günümüzde, Ibn Haldun'un eğitim hakkındaki görüşleri uzun dönemler boyunca sağlam kalacak siyasi nizamları tesis etmenin önemine dair mühim unsurları içermektedir. Bu makalede, Ibn Haldun'un eğitimi devletlerin ömrünü uzatan ve hanedanların önlenemez çöküşünü erteleyen başlıca amillerden biri olarak gördüğünü savunmaktayız. Makalenin ilk bölümünde ibn Haldun'un görüşlerini literatürdeki üç hakim tartışmaya nispetle konumlandırıyoruz. Bu tartışmaların ilki, Mukaddime'nin normatif mi yoksa deskriptif (betimleyici) mi olduğu; ikincisi, eserdeki beşeriyet tarihinin seyrine dair tutumun iyimser mi yoksa kötümser mi olduğu; üçüncüsü ise müellife göre

\footnotetext{
" This article is a review of the paper presented at the "4th International Ibn Khaldun Symposium" organized on 19-21 May 2017 in Istanbul.
} 
siyasetin rolünün ne olduğu soruları etrafında dönmektedir. Makalenin ikinci bölümünde, müellifin, eğitimi devletin en âlî maksadı olan içtimâ-i beşeriyyeyi kemale erdirmesi için gerekli olan ortamı sağlamaya giden en hayati yollardan birisi olarak kabul ettiğini tespit ediyoruz. Bu bölümde ayrıca, ilmi eğitimin devletin hayatiyetini hem devletin müstakbel idarecilerini yetiştirerek hem de devletin fikri ve ahlaki havasına kemal kuşandırarak nasıl desteklediğini izah ediyoruz. Makalemizin sonuç bölümünde ise ibn Haldun'un teklif ettiği eğitim pedagojisi ve ideal eğitmen modelini değerlendiriyoruz. Makalemizde islam ve Batı siyaset düşüncesini cem ederek Müslümanlara kendi fikri geleneklerinde ne gibi siyasi teklifler bulunduğunu göstermeyi hedeflemekteyiz. En nihayetinde, Ibn Haldun'un fikriyatını ait olduğu islami gelenek içerisinde anlamlandırmaya çalışarak Batı-merkezci siyaset teorisi alanının ufkunun genişlemesine katkı sunmayı ümit ediyoruz.

Anahtar Kelimeler: Ibn Haldun, Eğitim, IImi Eğitim, Siyaset, Siyaset Bilimi

\section{Introduction}

Hailed as "one of the fathers, of modern cultural history and social science," (Mahdi, 1968: 56), Ibn Khaldun is credited with writing "undoubtedly the greatest work of its kind that has ever been created by any mind in any time and place" (Toynbee, 1934: 372). His most famous work is the Muqaddima ("The Prolegomena" published in 1377 AD) in which he proposes a new science of culture as an auxiliary for historiography. In it, he demonstrates how the transition from primitive to advanced culture is the primary cause for the cyclical rise and fall of states. He famously writes that "as a rule, no dynasty lasts beyond the life (span) of three generations" 1 and adds: "If the time is up, (the end of the dynasty) cannot be postponed for a single hour, no more than it can be accelerated" (M3.12: 343). The new science of culture bleakly portrays the march of history as condemned to an inevitable cycle of human societies.

The dominant view in Western scholarship sees Ibn Khaldun as simply a fatalistic describer of the mechanistic workings of human societies who offers no legitimate hope of righting mankind and altering history. ${ }^{2}$ However, recent political theorists have challenged this perspective and have argued that Ibn Khaldun, despite painting this unwelcoming picture of human reality, tries to show how humans might intervene to

\footnotetext{
1 A/-Muqaddima, trans. Franz Rosenthal (3 vols., New York, 1958), Vol. 1, ch. 3, Section 12, p. 343. Henceforth, references will cite chapter, section and page number (but not volume) as follows: M 3.12: 343. 2 See H.A.R. Gibb, "The Islamic Background of Ibn Khaldūn's Political Theory"; British Cooper Busch, "Divine Intervention in the "Muqaddimah" of Ibn Khaldūn"; H.V. White "Comparative Studies in Society and History"
} 
guide the process of their society's development. ${ }^{3}$ Nevertheless, few of these theorists have traced the link between the political and educational systems presented in the Muqaddima. To address this gap in the scholarship, I examine Ibn Khaldun's model of education as encompassing his perspective on the ultimate aims of statecraft (advancing the crafts and sciences). I argue that Ibn Khaldun view scientific instruction ${ }^{4}$ as a crucial element for prolonging the polity and postponing the inevitable fall of dynasties. In the process, I demonstrate the normative dimensions of the Muqaddima, provide support for an optimistic reading of his new science, and offer insights on the primacy of human agency in prolonging the dynasty's life.

In this paper, I open with a summary of Ibn Khaldun's new science. Afterwards, I discuss how the good state facilitates the quest for human perfection by providing the context necessary for the sciences and crafts (which includes scientific instruction) to develop. Then, I explain how instruction strengthens the political well-being of the state by educating future leaders. Finally, I explore the proper teaching pedagogy of the ideal instructor that is necessary for effective education. In the process, I demonstrate how instruction and politics both mutually support the growth of the other and thereby, illustrate the imperial importance of scientific education for a wellfunctioning polity.

The methodology employed is borrowed from Kathryn Leigh Jenco's work in the emerging field of comparative political theory (Jenco, 2007 and 2011). In consonance with her "methods-centered approach to cross-cultural engagement," the paper contributes to the de-parochialization of western-dominated political theory by contextualizing Ibn Khaldun seriously within his Islamic tradition. ${ }^{5}$ In this regard, the paper attempts to interpret Ibn Khaldun within his Arabic and Islamic epistemic context whenever possible by defining his concepts and explaining his problems according to

\footnotetext{
3 See Malik Mufti, "Jihad as Statecraft”; James Morris, "An Arab" Machiavelli”?: Rhetoric, Philosophy and Politics in Ibn Khaldun's Critique of Sufism"; Muhsin Mahdi, "Ibn Khaldun's Philosophy of History. a study in the philosophic foundation of the science of culture"; Lenn Evan Goodman, "Ibn Khaldun and Thucydides" 4 The term 'scientific' refers to all academic disciplines including the traditional sciences on the one hand and the rational sciences on the other.

${ }^{5}$ For example, it would be extremely problematic to interpret Ibn Khaldun as one would Montesquieu without first situating his thought within the Islamic worldview, which is separated temporally and epistemically from its Western counterpart.
} 
his tradition's independent epistemology. ${ }^{6}$ By using this approach, I provide a more faithful account of Ibn Khaldun's writings.

\section{Ibn Khaldun's "New Science of Culture"}

Ibn Khaldun is most recognized for his Muqaddima (Prolegomena) to his seven-volume Kitab al-Ibar (The Book of Instructive Lessons) in which he proposes a 'new science of culture' for effective historiography that is subsequently demonstrated in the Kitab a/Ibar (Butterworth, 2004: 445). The objective of Ibn Khaldun's new science of culture is to mitigate historiographical errors by providing "a sound yardstick with the help of which historians may find the path of truth and correctness where their reports are concerned" ( $M: 77)$. To authenticate historical material, the new science differentiates "right from wrong in historical information on the grounds of (inherent) possibility or absurdity" (M: 77). Its subject is human culture because for Ibn Khaldun, any study of history "is information about human social organization, which itself is identical with world culture" ( $M: 71)$. To determine the boundaries of the rationally possible, the new science distinguishes between three categories within the cultural domain: "the conditions that attach themselves to the essence of culture as required by its very nature; the things that are accidental (to culture) and cannot be counted on; and the things that cannot possibly attach themselves to it" ( $M$ : 77$)$. The first category refers to the fundamental substance of an object that defines its identity. For example, the essence of a triangle is a shape with three sides since any increase in the number of sides changes its identity. The second category refers to essential properties and nonessential properties; the former are qualities that are necessarily associated with the object's essence and the latter are qualities that are not necessarily associated with its essence. An essential property of all triangles is that the sum of its angles is 180 degrees, whereas a nonessential property is its color or size, all of which can change without affecting its identity. Finally, the third refers to qualities that cannot be associated with the object because they do not rationally pertain. A triangle cannot be delicious or seductive because such qualities are not descriptively appropriate to its essence.

Ibn Khaldun identifies two 'first-principles' that form the essence of culture: first, humans are political by nature and second, different environments influence the

\footnotetext{
${ }^{6}$ See as examples "Ibn Khaldun and Islamic Mysticism" by M. Syrier, See "Ibn Khaldun's understanding of Civilizations and the Dilemmas of Islam and the West Today" by Akhbar Ahmed. P. 25 See also "Theorizing from Within: Ibn Khaldun and His Political Culture" by Lawrence Rosen. P.596, Syed Hossein Nasr "Conditions for Meaningful Comparative Philosophy."
} 
human body and character distinctively (Dale, 2006: 437). The reason for the first principle is that "human social organization is something necessary" for the most basic human subsistence because "the power of the individual human being is not sufficient for him to obtain (the food) he needs" ( $M, 1: 1: 89)$. In addition, "each individual needs the help of his fellow beings for his defense" $(M, 1: 1: 90)$. Human society is therefore necessary. However, Ibn Khaldun is aware that different peoples possess different conceptions of social organization. To account for these variances, he introduces a second principle that different environments influence the human body and character differently. This is best illustrated in his famous dichotomy of the primitive Bedouinswhich refers not just to nomadic desert dwellers, but also an intermediate group of herders and grazers who don't live in towns or cities-on the one hand and civilized urbanites living in luxury on the other hand. The harsh environment of the former influences their social organization structure and thus, demonstrates how the form of social organization depends upon the natural environment. These two principles outline the basic underpinning of culture across societies that all historians should be aware of and serve as the foundation for the new science.

In addition to these two 'first-principles,' the essential properties of culture, as Stephen Frederick Dale writes, are "royal authority, government, occupations, crafts, and sciences" (Dale, 2006: 436). Of paramount importance to Ibn Khaldun is the state, which "constitutes the form of the world, and of culture, which, in turn, together with the subjects, cities, and all other things, constitute the matter of (state and royal regime)" ( $M, 4: 17: 291)$. The state is needed to restrain aggressive tendencies and reconcile conflict that otherwise would lead to the dissolution of society. This is because "aggressiveness and injustice are in the animal nature of man" and will become manifest without a powerful restraining influence and neutral arbiter. Thus, "royal authority is a natural quality of man which is absolutely necessary to mankind" [italics added] $(M, 1: 1: 92)$.

\section{Politics in Scientific Pursuit}

The birth and subsequent growth of the sciences entails the establishment of a polity, for without it, humans "would be unable to have a complete existence" ( $M$ 6.3: 417). "When mankind has achieved social organization... and when civilization in the world has thus become a fact, people need someone to exercise a restraining influence and keep them apart" (M.1: 91). The state satisfies the most basic human needs for food, shelter, and defense by protecting the community against internal and external aggression. In addition to securing the necessities for basic human subsistence, the 
state is also entrusted with a higher order: to contribute towards realizing society's normative vison for the "complete existence." The fundamental purpose of politics is to provide the context necessary for perfecting the intellect in its rational and spiritual dimensions. Its development leads to complete existence because "God distinguished man from all the other animals by an ability to think which He made the beginning of human perfection and the end of man's noble superiority over existing things" (M 6.1: 411). ${ }^{7}$ One way to measure intellectual development is society's contributions towards the sciences and crafts. This is because when intellectual development becomes a fact in society, it leads to the advancement of the sciences and crafts, "which result from that ability to think" ( $M$. Introduction: 84 and $M$. 5.16: 347). Using the sciences as a measure, the state should facilitate the quest for human perfection by providing the context necessary for the sciences and crafts to develop (Mufti, 2009: 387; Mahdi, 1964: 173; Goodman, 1972: 250-70; Morris, 2008: 242).

Such a state must develop past primitive culture (badawi)-concerned only with securing the necessities for survival-to civilized culture (hadhari)-concerned with securing luxuries (Baali, 1988: 100). ${ }^{8}$ This entails advancing culture and achieving civilization because "the sciences are numerous only where civilization is large and sedentary culture highly developed" (M. 6.8: 434). Since civilized "culture in cities comes from the dynasties" and "is firmly rooted when the dynasty is continuous and firmly rooted," the advancement of culture requires a robust and stable state (M. 4.17: 286). This is because political stability provides the requisite time for the diversification of the crafts to become firmly rooted.

In addition to durability, advanced culture also entails economic prosperity (Mufti, 2009: 387). A surplus of wealth provides the possibility for leisure time and allows individuals to fully dedicate their time and labor to other ends beyond merely securing the necessities for existence. One of the central mechanisms by which economic surplus is secured and leisure time afforded is the development of simple crafts (M: 5.23: 357). During the early stages of society (primitive culture), the simple crafts are concerned only "with the necessary in food, clothing, and mode of dwelling, and to the other necessary conditions and customs" (M 2.2: 250) and "exist only in as much as they are needed, since all of them are means to an end and are not intended for their own sake" (M: 5.16: 348). As the culture advances, these simple crafts are refined as

\footnotetext{
7 The point is reiterated in $M 1$.Preface: $84 ; 6.16: 77 ; 6.22: 137$

8 Also, see M, 4.17: "Sedentary culture is a condition that is the result of custom and goes beyond the necessary conditions of civilization."
} 
"men learn to improve the methods of production" and eventually produce an economic surplus (Mahdi, 1957: 221). They thus eventually yield two key byproducts both of which are directly necessary for further advancing culture: (1) expendable wealth and (2) leisure time.

The availability of excess wealth and time brings about an increased demand for luxury. "When the city is organized and the (available) labor increases and pays for the necessities and is more than enough (for the inhabitants), the surplus is spent on luxuries" (M. 5.16: 347). The new demand for luxury spawns the "refinement and development" of several added crafts (which will be referred to as the "developed crafts'), each "perfected with every finesse...as luxury-customs and conditions demand" (M. 5.16: 348). But beyond the satisfaction of luxury-and indeed loftier-is the pursuit of knowledge and the development of the speculative intellect. Ibn Khaldun writes: "When civilized people have more labor available than they need for mere subsistence, such (surplus) labor is used for activities over and above making a living. These activities are man's prerogative. They are the sciences." Accordingly, scholarship requires a state that possesses a resource surplus and enjoys luxuries because the possibility of leisure ensures that scholars can fully devote their time towards research without worrying about making a living. It follows therefore that the refinement of the crafts, economic prosperity, and political stability lead to the advancement of culture and are therefore, central characteristics of the good state.

Among the developed crafts is scientific instruction. ${ }^{9}$ Like the other developed crafts, its existence, "depends on the greater or lesser extent of civilization in the cities and on the sedentary culture and luxury they enjoy" (M. 6.8: 434). In so far as craft development leads to the advancement of culture, it follows by logical extension that the state should secure the conditions necessary for the development of scientific instruction. This conclusion, however, presupposes that scientific instruction is equivalent to the other developed crafts, but this is not the case. According to Ibn Khaldun's normative standard, scientific instruction is superior because it contributes to intellectual and scientific growth more than other crafts. Without instruction, man would remain perpetually confined to a natural state of ignorance $(M .6 .6: 425)^{10}$ since

\footnotetext{
9 See M. 6.7: 426. "Scientific instruction is a craft."

$10 \mathrm{lbn}$ Khaldun mentions the task of perfecting the body first before working on the intellect. He quotes a passage from the Quran demonstrating the perfection of the body first, which of course includes the intellect (mind and heart) as a prerequisite for the perfection of existence (i.e. the internal state). Hence, the external precedes the internal. He writes, "He [God] let him acquire knowledge he did not yet possess, after he had been a clot of blood and a lump of flesh."
} 
he "is essentially ignorant, and becomes learned through acquiring (knowledge)" ( $M$. 6.6: 424). According to Ibn Khaldun, the primary, if not only, method of advancing beyond the nescient tabula rasa is through education. Beyond childhood education, scientific instruction is also required for inculcating scientific habits and training scholars for scientific research. Ibn Khaldun emphasizes this point when he writes: "a tradition of famous teachers with regard to instruction in any science or craft, is acknowledged (to be necessary) by the people of every region and generation (race)" (M. 6.7: 426). The relationship between science and instruction is a relationship of dependency whereby the advancement of the sciences is dependent on instruction. Scientific instruction should therefore be accorded a higher status for its direct function in contributing towards scientific growth unlike any one craft.

From that preceding proposition, it follows that the state should be more concerned with cultivating instruction than the other developed crafts. The inevitable question that follows is: in what ways should the state be involved in education? Ibn Khaldun provides an answer when he discusses the reasons why scientific instruction persisted in Cairo "for many thousands of years." He points to the actions of the "Turkish Emirs under the Turkish dynasty" and says:

"They built a great many colleges, hermitages, and monasteries, and endowed them with mortmain endowments that yielded income. They saw to it that their children would participate in these endowments, either as administrators or by having some other share in them. (This was their intention) in addition to the fact that they were inclined to do good deeds and hoped for (a heavenly) reward for their aspirations and actions. As a consequence, mortmain endowments became numerous, and the income and profit (from them) increased. Students and teachers increased in numbers, because a large number of stipends became available from the endowments"(M. 6.8: 435).

At face value, this passage describes the state of scientific instruction under the Turkish Emirs. Because of his normative preoccupation with intellectual and scientific advancement, Ibn Khaldun appreciates the Emirs' financial support for scientific instruction. In funding the construction of scholarly institutions and providing endowments to support scholars working in them, the Emirs were doubly concerned with (1) the physical existence of schools as well as (2) the production of scholarship within those schools. Because of their support for scientific instruction, "people traveled to Egypt from the 'Iraq and the Maghrib in quest of knowledge" because "the 
sciences were very much in demand and greatly cultivated there." Egypt thus became the center of learning under the Emirs' reign.

This passage generally outlines the relationship between the statesmen and scientific instruction. The former should provide financial support for (1) the preservation of the sciences and (2) the establishment of institutions and scholars within them in order to advance the sciences. ${ }^{11}$ In summary, as Muhsin Mahdi writes: the state must secure "the possibility of leisure, the continuity of a civilized tradition, the social demand for the services of the learned, and the appreciation and encouragement of the rulers of their profession as expressed in their generosity in establishing schools and founding endowments to maintain them" (Mahdi, 1957: 222). However, the state's role in education should be limited to providing the context necessary for the development of the sciences (which primarily entails financial contributions). It should not influence the educational curriculum or how scientific development proceeds.

\section{The Political Benefits of Instruction}

The relationship between politics and instruction consists not only of the state securing the conditions necessary for a flourishing teaching tradition but also of instruction in strengthening and perfecting the state. Instruction contributes towards political wellbeing by educating future political leaders and thereby, perfecting the character of the state. Ibn Khaldun identifies three core components of political education for the statesman to rule successfully: (1) religion; (2) history; (3) and the practical sciences. The letter of Tahir b. al-Husayn addressed to his son 'Abdallah b. Tahir comments upon all three components by discussing "all (important) political problems as handled by the religious law and all problems of power politics that he would have to know in his government and administration" and thus, will serve as the primary material of this section's analysis.

The letter of Tahir b. al-Husayn, al-Ma'mun's general, addressed to his son 'Abdallah b. Tahir when he was appointed governor of al-Raqqah highlights three important components that should comprise political education. The first is instruction in the religious law; the second is an examination of history as well as current political leaders; and the third is knowledge of the different branches of rule and the proper

\footnotetext{
11 It should be noted that Ibn Khaldun's critique of the second righteous Caliph does not entail total disregard for his religious reign in the same way that his specific approval of al-Ma'mun's attitude towards scientific preservation does not elicit wholesale support for the Mihnah (trial) where the Caliph violently persecuted any religious scholar resisting the Mu'tazili rationalist school of Islamic theology.
} 
course of leading in each. Beginning with the stateman's religious education, Ibn Khaldun describes the letter as "advice concerning all religious and ethical matters" and discussing "all (important) political problems as handled by the religious law" (M. 3.50. 139). In fact, almost every paragraph in the letter exhorts 'Abdallah to develop an Islamic personality and follow the divine legislation. In one place, Tahir reminds 'Abdallah that "whatever you do, you should do for God and in God, and hope for a reward" (M. 3.50. 147) and in another place, he commands his son to "apply the punishments that God has ordained for criminals, according to their station and according to what they deserve" (M. 3.50. 144). Under the typical Muslim ruler in the Muslim empire, this heavy emphasis on exhorting political leaders to develop an Islamic personality and obey the divine law are to be expected. However, this letter was not written during the reign of a typical Muslim ruler; it was written during the Caliphate of al-Ma'mun, who is famed for criticizing literal obedience to the divine law and supporting the use of unaided reason for understanding theology as well as religious legislation governing social affairs. Despite his defiant stance towards observing the letter of the religious law, he nonetheless "ordered the letter to be sent to all officials in the various regions, so that they might use it as a model and act accordingly" (M. 3.50. 156). His actions here raise an important question: given the countless exhortations to follow the divine law and not unaided reason in Tahir's letter, why did al-Ma'mun approve its circulation? This question is further complicated since the family of Tahir also heavily supported al-Ma'mun's religious agenda of privileging reason as the final arbiter (Bosworth, 1969: 45-79). As Gutas states, they had always played an important role "in early 'Abbasid history both in furthering and executing the policies of those members of the "Abbasid house" (Gutas, 1998: 98). Though no one can claim with certainty that Tahir believed in the Mu'tazili school (the rationalist trend in Islam that al-Ma'mun promoted), he nevertheless helped create "a cultural and ideological climate" favorable towards al-Ma'mun's religious policies (Gutas, 1998: 98). Given (1) the Caliph al-Ma'mun's personal approval of Tahir's letter and (2) Tahir's support for the Caliph's sanctioning of the Mu'tazili school as the official state doctrine and persecution of those who disagreed, the letter's emphasis on obedience to the religious law seems unusual. Why would supporters of the Mu'tazili school write and approve of a letter calling on statesmen to follow the religious law for social affairs when according to their theology, reason has the ultimate authority in the political sphere? The answer is straightforward; Tahir and al-Ma'mun saw a rational reason for obeying Islamic law in the political sphere. I argue that the letter's injunction to obey divine law can be explained using Ibn Khaldun's rational argument for why religionespecially Islam-is politically useful. To make this argument, I will first explore his discussion on religion and politics. 
Ibn Khaldun argues that political authority requires group feeling (asabiyyah), which refers to tightly knit bonds of solidarity that exist between closely connected members of one group. It is a powerful force for political association such that "leadership exists only through superiority, and superiority only through group feeling" (M. 2:11:269). Possessing the most political talent alone is not sufficient for obtaining leadership or power; rather, it requires enjoying a shared, ascriptive connection with the people, and this is only achieved through group feeling. Accordingly, the political leader must utilize this asabiyyah to gain legitimacy from his people as someone worthy of their loyalty and obedience.

In the Arab context, the strongest asabiyyah that led to political unity and military strength was their shared religious attachment towards Islam. Ibn Khaldun illustrates Islam's power for political association by depicting its influence on the Arabs:

"When there is a prophet or saint among them, who calls upon them to fulfill the commands of God and rids them of blameworthy qualities and causes them to adopt praiseworthy ones, and who has them concentrate all their strength in order to make the truth prevail, they become fully united (as a social organization) and obtain superiority and royal authority" (M. 2.26. 305-06).

Here, Ibn Khaldun describes two ways that Islam promoted unity among the Arabs. On the one hand, its restraining influence mitigated those human qualities that are detrimental to the integrity of the community (like jealousy or envy). On the other hand, its communitarian message privileged the well-being of the believers above individual ambitions. Coupled with the collective religious obligation to spread the truth, Islam created an unbreakable group feeling (asabiyya) that transformed the Arabs from disparate tribes constantly engaged in petty squabbles to a strong, unified community. It was the primary impetus that led to rapid expansion, state development, and dynastic growth. In summary, Ibn Khaldun's argument for Islam's political utility is as follows: (1) political leaders must understand and identify with the group feeling to successfully rule; (2) the strongest asabiyyah in the Muslim world is their shared religious attachment towards Islam; (3) therefore, the political leader must understand and identify with Islam.

Ibn Khaldun's rational reasoning for Islam's political utility offers a guiding framework for understanding Tahir's letter. Many of Tahir's exhortations to 'Abdallah stem from its potential to create a powerful asabiyya. He tells his son: "when people notice your (religious attitude) they will have respect for your rule and reverence for your 
government. They will be friendly to you and trust in your justice." In another place, he says: "have a good opinion of God, and your subjects will cause you no trouble." Tahir connects the political leader's zealousness for religion with receiving greater public support, but to have its effect, the people must notice his religiosity. Hence, the first quote is a conditional statement where receiving public respect depends upon visibly displaying his concern for religion. This is why Tahir not only commands the "unfailing fulfillment of the duty of the five daily prayers that God has imposed upon you" but also, "let people come to you to pray together with you, and perform (the prayers at the proper times) with all their rites."12 Tahir's religious exhortations therefore suggest a concern with garnering political support through asabiyyah and thus, align with Ibn Khaldun's views on the political utility of Islam.

The preceding discussion sheds light on why political leaders must be educated in religion. Since they must align their political agenda and methods of rule according to popular beliefs as much as possible, they must learn about asabiyya, its function in governance, and how to use it for political advancement. In the context of the Muslim empire, this means learning Islam, inculcating its virtues, and practicing what it mandates at the personal level. The statesman must also learn about the religious law and the customs of the people. His education should not only demonstrate how to develop an Islamic personality but in the context of politics, how to protect and mobilize the group feeling to achieve the political good. This is the first component of political education that Ibn Khaldun refers to.

The second component of political education found in Tahir's letter is history. Tahir says: "Learn from the affairs of the world that you are able to observe personally, and from the persons in authority and in positions of leadership who lived before your time in past centuries" (M. 3:50.154). Studying history offers lessons for statecraft because "the causes of action, and the reasons for the policies upon which action is based, remain constant or do not vary significantly from one age to another or from one people to another" (Mahdi, 1957: 70). By examining the actions of previous political leaders, the statesman learns lessons on how to administer the community's affairs. In addition, the study of history provides rulers with political experience, a necessary characteristic of the good statesman. Tahir highlights the importance of political experience when he orders his son to "employ for them [the people] understanding,

\footnotetext{
12 According to Ibn Khaldun, Islam is the best model for achieving political success because it fosters an unbreakable group feeling that incorporates communal and private worship. Zeal for communal worship represents an external indication of a person's religiosity and thus, proves instrumental for demonstrating the political leader's attachment towards Islam.
} 
skilled, and experienced men, who have theoretical knowledge of, and are able to act with, political wisdom and moderation" [italics added]. The meaning of political experience here refers not only to personal experience but also experience derived from studying political history. Thus, teaching practical lessons about statecraft through studying history equips the statesman with political experience and thereby, makes history a central component of political education.

The political value of studying history is one of the fundamental reasons Ibn Khaldun wrote the Muqaddima and his Kitāb al- 'ibar ('Book of Lessons'). In the title of his second work, Ibn Khaldun's use of the word "Ibar" (translated as 'Lessons') captures how studying history is politically useful. According to Lane's Lexicon, the definition of Ibar is to penetrate from the outside to the inside of a thing. ${ }^{13}$ In the context of history, it suggests delving beneath the surface of the particular events to extract timeless principles (Mahdi, 1957: 64-68). The imagery evoked here matches the distinction Ibn Khaldun makes in the Muqaddima between external and internal history. The first is "no more than information about political events, dynasties, and occurrences of the remote past, elegantly presented and spiced with proverbs" whereas the second is the "explanation of the causes and origins of existing things, and deep knowledge of the how and why of events" (M. Forward, 6). The latter describes the subject-matter of the Muqaddima and is also the only type that is politically useful because it provides enduring lessons for politicians. Moreover, in the larger title of Kitāb al- 'ibar (El-Rayes, 2008: 37), ${ }^{14}$ he qualifies the term 'history' to 'dealing with political events,' suggesting that his derived general laws have political value. Accordingly, the Kitāb al- 'ibar and therefore the Muqaddima become more than just general works of history but rather scholarship that instructs political statesmen. Ibn Khaldun's writings are therefore examples of the types of historiographical scholarship future statesmen should study.

The third component of political education that Tahir's letter to his son 'Abdallah references is learning about the political, economic, and military systems. The future statesmen should understand how the state functions and what its division of offices are. Thus, Tahir orders his son to understand "the administration of [the people's]

\footnotetext{
13 See Lane's Lexicon (II), p. 1988-1991

14 See chapter 2 of "The Political Aspects of Ibn Khaldun's Study of Culture and History" by El-Rayes for an extensive analysis of the full title Kitāb al-'Ibar wa dīwān al-mubtada' wa al-Khabar fí ayyām al-'arab wa al'ajam wa al-barbar wa man 'āsarahum min dhawī al-sultān al-akbar (Book of Lessons and Archive of Early and Subsequent History, Dealing with the Political Events Concerning the Arabs, Non-Arabs, and Berbers, and the Supreme Rulers Who Were Contemporary with Them)
} 
affairs." This includes "the land tax" because "it maintains the subjects," setting "up houses for Muslims who are ill, to shelter them," establishing "the office of judge" to apply the legal punishment, and supervising "the registers and contracts of the soldiers" (M. 3:50: 150-51). These subjects roughly correspond to political science, economics, community health, law, and military leadership respectively. They all are concerned with understanding the current context and directing man accordingly towards achieving his true end. In summary, political instructors are responsible for producing good statesmen that can lead and grow the polity. The three components of political education, namely religion, history, and the practical sciences, demonstrate how instruction benefits politics by strengthening the state and therefore, offer an additional reason for why the state should provide the context necessary for realizing a strong teaching tradition. By underscoring the mutual necessity of education for a well-functioning state, Ibn Khaldun also raises important questions about who the instructors should be. What qualities should they have and what methodologies must they employ? The next section will explore how Ibn Khaldun answers these questions.

\section{The Four Principles of the Ideal Teaching Pedagogy}

Ibn Khaldun provides a set of four principles necessary for effective instruction, all of which illustrate his pragmatic approach to education: (1) gradualism; (2) flexibility; (3) dialogue; and (4) leniency. Beginning with the first, gradualism is required because "teaching of scientific subjects to students is effective only when it proceeds gradually and little by little" (M. 6.36: 292). This is especially pertinent for habit cultivation, which needs consistent repetition over long durations of time. To illustrate this point, Ibn Khaldun divides scientific instruction into three distinct stages for effectively developing scholarly habits. In the first stage, the instructor summarily presents the principal problems of the subject. In the process, the student "acquires the habit of the science (he studies)," but it "will be an approximate and weak one. The most it can do is to enable the student to understand the discipline (he studies) and to know its problems" (M. 6.36: 292). In the second stage, the instructor explores some of its finer problems and nuances as well as "mentions to him the existing differences of opinion and the form these differences take" (M. 6.36: 292). Consequently, the student's scientific habits are improved. Finally, in the third stage, the instructor details the entire subject leaving "nothing (that is) complicated, vague, or obscure, unexplained. He bares all the secrets (of the discipline) to him" (M. 6.36: 292). At the end, the student, "when he finishes with the discipline, has acquired the habit of it." 
The threefold repetition process is "the effective method of instruction" for habit cultivation (M. 6.36: 292). Without gradualism, instruction will overwhelm students having no prior familiarity with learning the sciences because it expects them to instantly understand challenging concepts. If immediately introduced to complex material, pupils will either spend more time learning the science than necessary or become overwhelmed and leave scientific learning on account of its difficulty. To avoid either outcome, the three-stage model gradually presents information in order to ultimately ensure that students intellectually progress and acquire scientific habits according to their capabilities.

The second principle, flexibility, requires instructors to alter their teaching pedagogy according to the students' receptivity. This entails that the teacher 'observes the student's intellectual potential and his preparedness for understanding the material that will come his way until the end of the discipline under consideration (is reached)" (M. 6.36: 292). The word "observes" here suggests that instructors monitor their students to assess their intellectual potential. Ibn Khaldun mentions two conditions that they must consider. The first is 'the classroom dynamic' produced when students interact with one another. Teachers must understand how this interaction influences individual students and therefore, affects their learning. The second condition is each student's individual receptivity to instruction. The teacher must intimately know each student, how they learn best, and their intellectual strengths as well as weaknesses. Taken together, both conditions comprehensively assess the individual and communal components of student learning. To understand both, the instructor should know about student psychology.

In assessing both conditions, instructors will find that each student possesses a different intellectual capability. Ibn Khaldun illustrates this point when he writes: "Some students can get through it [education] with less than that [three stages of instruction], depending on their natural dispositions and qualifications" (M. 6.36: 29293). He identifies here "natural disposition" and acquired "qualifications" (the student's upbringing and previous education) as influencing intellectual character. The former is rooted in nature and the latter in nurture; both significantly vary from student to student. Given this diversity, the instructors cannot impose a universal teaching methodology but instead must modulate their approach accordingly. This entails not only understanding each student's capabilities but also the best way to maximize their intellectual potential. Moreover, unexpected situations may arise because of accidental 
conditions. Given the diversity of subjects and the unpredictability of contingencies, instructors must therefore modulate their teaching pedagogy accordingly. ${ }^{15}$

The third principle, dialogue, requires original student articulation of the subject matter. Dialogical processes measure not only an understanding of the material but also the ability to critically evaluate information through discussion. On this point, Ibn Khaldun writes: "Some students spend most of their lives attending scholarly sessions. Still, one finds them silent. They do not talk and do not discuss matters. More than is necessary, they are concerned with memorizing. Thus, they do not obtain much of a habit in the practice of science and scientific instruction" (M. 6.7: 429). Without discussing what they learned, students will not fully comprehend the subject-material and therefore, will not firmly develop scientific habits. This is because "the easiest method of acquiring the scientific habit is through acquiring the ability to express oneself clearly in discussing and disputing scientific problems" (M. 6.7: 429). This quote highlights two forms of student articulation: first, discussion and second, disputation. The former ensures that students have a basic understanding of the material whereas the latter tests their critical thinking by forcing them to defend their views. Disputation thus comes after discussion and helps firmly solidify their knowledge.

Dialogue mutually benefits both educators and pupils because communication "either through instruction or through discussion" strengthen the ability to think (M. 6.33: 281 ). On the one hand, students must engage in discussion to cultivates their intellect. On the other hand, instruction also deepens the teachers' comprehension because they present the material through various approaches. Moreover, classroom discussions can generate scientific insight beneficial to both teachers and students. Dialogical instruction thus represents a teaching model that maximizes instructional value for multiple actors.

Finally, the fourth principle, leniency, should be the norm because "severe punishment in the course of instruction does harm to the student, especially to little children, because it belongs among (the things that make for a) bad habit" (M. 6.39: 305).

\footnotetext{
15 It is important to emphasize that Ibn Khaldun's conception of differences based on both nature and nurture entails that this diversity is respected and incorporated in teaching pedagogy. However, this is not suggestive of radical equality such that teachers restrict the development of more talented students to uplift others. Rather, should a student be considered more gifted than his peers, the teacher should cultivate that skill by giving him special attention. Equalization of opportunities thus does not entail sameness but rather that each student possesses the necessary means to effectively realize their intellectual potential.
} 
Continuous harsh punishments destroy the children's fortitude and cause harmful characteristics to develop. Additionally, they sap their confidence in knowledge acquisition until they eventually leave the pursuit of science altogether. "Thus, they fall short of their potentialities and do not reach the limit of their humanity" (M. 6.39: 305). To perfect the student's potentiality, the teacher should tend towards leniency, preferring clemency over severity. Ibn Khaldun illustrates this point when he quotes Ar-Rashid saying: "Do not always be too lenient with him [the student], or he will get to like leisure and become used to it. As much as possible, correct him kindly and gently. If he does not want it that way, you must then use severity and harshness" (M. 6.39: 307). He urges the instructor here to begin with kindness in gently correcting the student; if it does not work, the instructor should subsequently resort to severity. Though punishment is the last option, it nonetheless is needed for stubborn students who refuse to accept the teacher's authority. Ar-Rashid's quote highlights an important balance that the instructors must maintain. On the one hand, they should not be overly lenient with obedient students because they "will get to like leisure." On the other hand, they should not be overly severe to obstinate students because they will develop bad habits. In both cases, Ibn Khaldun does not rule out using force in instruction but instead attempts to limit its use. He calls for a balance between severity and leniency, although tending more towards the latter in most cases.

Taken together, these four principles constitute Ibn Khaldun's pragmatic teaching framework. He does not put forth a universal teaching method but instead and like his approach to politics, expounds on the fundamental, unchanging principles that must guide every pedagogical model. Thus, his proposed outline is adaptable to diverse situations based on differences among students, local customs, as well as accidental conditions that may arise. It places considerable responsibility on instructors to find creative ways to maximize their students' intellectual potential and thus, privileges their human agency. Because conditions change constantly and unpredictably, such adaptation cannot be reduced to a universal formula. The imprecision of instruction requires the art of maintaining balances to sustain a flourishing teaching tradition. Ibn Khaldun's pragmatic approach to pedagogy ensures the continuity of effective education and therefore, prolongs scientific instruction's positive influence on political well-being.

\section{Conclusion}

At a time when various forces threaten the continued life of democracy, Ibn Khaldun's writings on education offer renewed importance to building longer lasting political 
regimes. From the outset, his views on history seem to be a fatalistic description of the mechanistic workings of human societies. This cycle of the rise and fall of civilizations begins with the rapid growth of the first generation, which "retains the desert qualities, desert toughness, and desert savagery;" reaches its peak in the second generation, which "changes from the desert attitude to sedentary culture, from privation to luxury and plenty;" and rapidly declines in the third generation, which "has (completely) forgotten the period of desert life and toughness, as if it had never existed" and "becomes dependent on the dynasty and are like women and children who need to be defended (by someone else)" (M. 3.12: 344-45 ). Another 'desert' group seizes power after the third generation and destroys the dynasty.

Given this depiction of the almost mechanical cycle of states and dynasties, many Western scholars describe Ibn Khaldun as a pessimistic thinker who envisions no possibility for reform. However, I demonstrate in this paper that Ibn Khaldun, despite negatively portraying the course of history, tries to show how humans might intervene to guide the process of their society's development. I focused on Ibn Khaldun's conception of scientific instruction and argued that he views education as a crucial element for prolonging the polity and postponing the inevitable fall of dynasties. My analysis shows how he foresees the possibility for positive change through education and therefore, is cautiously optimistic in the potential to stave off civilizational degeneration and prolong the dynasty's life.

In this paper, I demonstrated how instruction and politics both mutually support the growth of the other. On the one hand, the good state must facilitate the quest for human perfection by providing the context necessary for the sciences and crafts (which includes scientific instruction) to develop. This is because the fundamental purpose of politics is to contribute towards realizing society's normative vison for the "complete existence," namely, the development and perfection of the intellect. Since scientific instruction contributes to intellectual and scientific growth more than any other craft, the state should ensure the existence of a teaching tradition. On the other hand, I explained how instruction strengthens the political well-being of the state by educating future leaders. Additionally, I demonstrated how Ibn Khaldun's science of culture provides a practical, educational handbook for political statesmen on what to do and not do in the future and therefore is an attempt to interfere in postponing the 'inevitable' decline of civilization.

Finally, my discussion on Ibn Khaldun's teaching pedagogy demonstrates his realistic approach to instruction. His pedagogy places considerable responsibility on 
instructors to maximize their students' intellectual potentials. By doing so, Ibn Khaldun attempts to ensure not only the permanency of effective education despite changing political conditions but also its continued positive influence on the state's political well-being. Thus, his realistic approach to education illustrates his general optimism in reforming society and thereby, in prolonging the dynasty's duration. A shrewd diplomat, expansive scholar, and pragmatic political theorist, Ibn Khaldun offers a realist picture of scientific instruction and through it, seeks to build longer lasting political regimes.

\section{References}

Ahmed, A. (2002). Ibn Khaldun's understanding of civilizations and the dilemmas of Islam and the west today. The Middle East Journal, 56(1), 20-45.

Baali, F. (1988). Society, State, and Urbanism: Ibn Khaldun's Sociological Thought. Albany: State University of New York Press.

Baali, F., \& Wardi, A. (1981). Ibn Khaldun and Islamic Thought-Style: A Social Perspective. Library of Congress Cataloging in Publication Data.

Bosworth, C. E. (1969). THE TAHIRIDS AND ARABIC CULTURE. Journal of Semitic Studies, 14(1), 45-79. https://doi.org/10.1093/jss/14.1.45

Busch, B. C. (1968). Divine Intervention in the "Muqaddimah" of Ibn Khaldūn. History of Religions, 7(4), 317-329.

Butterworth, C. E. (2004). The Essential Accidents of Human Social Organization in the Muqaddima of Ibn Khaldun. In The Greek Strand in Islamic Political Thought (pp. 443-468).

Dale, S. F. (2006). Ibn Khaldun: The Last Greek and the First Annaliste Historian. International Journal of Middle East Studies, 38(3), 431-451. https://doi.org/10.1017/S0020743806412423

El-Rayes, W. (2008). The Political Aspects of Ibn Khaldun's Study of Culture and History. Retrieved from http://drum.lib.umd.edu/handle/1903/8529

Fischel, W. J. (1967). Ibn Khaldūn in Egypt; his public functions and his historical research, 13821406; a study in Islamic historiography. Berkeley: University of California Press.

Gannagé, E., Crone, P., \& Aouad, M. (2004). The Greek Strand in Islamic Political Thought. Melanges de l'Universite Saint loseph, 57.

Gibb, H. A. R. (1933). The Islamic Background of Ibn Khaldūn's Political Theory. Bulletin of the School of Oriental Studies, University of London, 7(1), 23-31.

Goodman, L. E. (1972). Ibn Khaldun and Thucydides. Journal of the American Oriental Society, 92(2), 250-270. https://doi.org/10.2307/600652

Gutas, D. (1998). Greek Thought, Arabic Culture: The Graeco-Arabic Translation Movement in Baghdad and Early 'Abbasaid Society. London; New York: Routledge.

Ibn Khaldūn, \& Rosenthal, F. (1967). The Muqaddimah: an introduction to history (2d ed., with corrections and augmented bibliography, Vols. 1-3). Princeton, N.J: Princeton University Press. 
Jenco, L. K. (2007). "What Does Heaven Ever Say?" A Methods-centered Approach to Crosscultural Engagement. The American Political Science Review, 101(4), 741-755.

Jenco, L. K. (2011). Recentering Political Theory: The Promise of Mobile Locality. Cultural Critique, 79, 27-59. https://doi.org/10.5749/culturalcritique.79.2011.0027

Mahdi, M. (1957). Ibn Khaldūn's philosophy of history: a study in the philosophic foundation of the science of culture. London: G. Allen and Unwin.

Mahdi, M. (1968). Ibn Khaldun. International Encyclopedia of the Social Sciences, 7, 53-57.

Mahdi, M. (1 966). Ibn Khaldun. In M. M. Sharif, A History of Muslim Philosophy (Vol. 2, pp. 888904, 961-984). Wiesbaden: Otto Harrassowitz.

Makdisi, G. (1981). The rise of colleges: institutions of learning in Is/am and the West. Edinburgh, [Scotland]: Edinburgh University Press.

Morris, J. W. (2008). An Arab“ Machiavelli”?: Rhetoric, Philosophy and Politics in Ibn Khaldun's Critique of Sufism. The Selected Works of James W. Morris, 33.

Mufti, M. (2009). Jihad as Statecraft: Ibn Khaldun on the Conduct of War. History of Political Thought, 30(3), 385-410.

Nasr, S. H. (1972). Conditions for Meaningful Comparative Philosophy. Philosophy East and West, 22(1), 53-61. https://doi.org/10.2307/1397959

Pines, S. (1971). The Societies Providing for the Bare Necessities of Life According to Ibn Khaldūn and to the Philosophers. Studia Is/amica, (34), 125-138. https://doi.org/10.2307/1595328

Rabī', M. M. (1967). The political theory of Ibn Khaldūn. Leiden, EJBrill.

Rosen, L. (2005). Theorizing from within: Ibn Khaldun and His Political Culture. Contemporary Sociology, 34(6), 596-599.

Stowasser, B. F. (1983). Religion and Political Development: Some Comparative Ideas on Ibn Khaldūn and Machiavelli. Center for Contemporary Arab Studies, Georgetown University.

Syrier, M. (1947). Ibn Khaldun and Islamic Mysticism. Islamic Culture, 21, 264-302.

Toynbee, A. (1934). A study of history. Vol. III. New York: Dell.

Walzer, R. (1963). Aspects of Islamic Political Thought: Al-Fārābī and Ibn Xaldūn. Oriens, 16, 40-60. https://doi.org/10.2307/1580252

White, H. V. (1959). Ibn Khaldun in World Philosophy of History: Review Article. Comparative Studies in Society and History, 2(1), 110-125. 